\title{
Pharmacoeconomics of antibiotic therapy
}

\author{
JACQUES LE LORIER MD PhD FRCPC
}

\begin{abstract}
J LE LORIER. Pharmacoeconomics of antibiotic therapy. Can J Infect Dis 1994;5(Suppl C):42C-44C. During the past few years new drugs with greatly improved efficacy have become available to physicians and their patients. The higher purchase price of these new drugs is quite important and is quoted as a significant cause of the escalating cost of health care. Antibiotics have played a highly visible role in this therapeutic scene and account for $\$ 1.2$ billion of the yearly national pharmaceutical budget in the United States. From an economic point of view, costs arise because resources are limited and have alternative uses. The real cost of prescribing a new, more expensive drug, may be that other drugs and/or services become unavailable. Unsurprisingly, considering the magnitude of the stakes, we have seen the recent development and expansion of subsets of the field of health economics. Of these, cost of illness studies and pharmacoeconomics have played a prominent role. The ultimate objective of these relatively new tools is to help clinicians and decision makers in setting priorities. A pharmacoeconomic study can have different perspectives. Cost and benefits can be calculated with respect to the patients', society's, the payers' or the health care providers' point of view. The perspective chosen for a study determines what is counted as cost or benefit; therefore, the economic impact of an intervention may be quite different depending on the perspective taken. Pharmacoeconomics is particularly relevant to antibiotic therapy since it can demonstrate that the price of acquisition of the drug plays a relatively modest part in the global pharmacoeconomic aspect of the treatment of bacterial infections. This is easily understood when it is realized that failure to treat a bacterial infection due to an inadequate choice of antibiotic promptly can result in avoidable hospitalization, prolongation of hospitalization, permanent disability and even death.
\end{abstract}

Key Words: Antibiotic therapy, Cost of illness studies, Pharmacoeconomics

\section{Enjeux pharmacoéconomiques de l'antibiothérapie}

RÉSUMÉ : Au cours des quelques dernières années, de nouveaux médicaments dotés d'une efficacité nettement améliorée ont fait leur apparition dans l'arsenal thérapeutique dont disposent les médecins pour traiter leurs patients. Le prix d'achat plus élevé de ces nouveaux médicaments est assez important et on lui impute en bonne partie la responsabilité du coût croissant des soins de santé. Les antibiotiques ont joué un rôle à l'avant-plan de la scène thérapeutique et représentent 1,2 milliard de dollars dans le budget pharmaceutique national annuel des États-Unis. D'un point de vue économique, les coûts s'élèvent parce que les ressources sont limitées et qu'elles sont utilisées à plus d'une fin. Le coût réel d'une ordonnance. dans le cas d'un médicament nouveau et plus cher, peut parfois être lié au fait que d'autres médicaments et/ou services ne sont plus disponibles. Il n'est pas étonnant, compte tenu de la taille des enjeux, que nous ayons récemment assisté à la création et au rayonnement de sous-spécialités dans le domaine de l'économie appliquée à la santé; que l'on songe au rôle prépondérant qu'ont joué certaines études sur les coûts de la maladie et la pharmacoéconomie. L'objectif final de ces outils relativement nouveaux est d'aider les cliniciens et les décideurs à établir leurs priorités. Or, une étude de pharmacoéconomie peut représenter différents points de vue, car les coûts et les avantages peuvent être calculés en fonction de leurs répercussions sur le patient, sur la société, sur les administrateurs de l'établissement ou sur le personnel soignant. L'angle sous lequel une étude est élaborẻe déterminera ce qui sera comptabilisé comme coût ou comme avantage et par conséquent, l'impact économique d'une intervention variera grandement selon la perspective de l'auteur. La pharmacoéconomie est particulièrement pertinente lorsqu'il est question d'antibiothérapie puisqu'elle peut démontrer que le prix d'acquisition du médicament joue un rôle

continued on next page

Departments of Medicine and Pharmacology, University of Montreal, Montreal, Quebec

Correspondence and reprints: Dr J Le Lorier, Research Center, Hôtel-Dieu de Montréal, 3850 rue St-Urbain, Montréal, Québec H2W 1T8, Telephone (514) 843-2918, Fax (514) 843-2715 
relativement modeste dans l'ensemble des enjeux pharmacoéconomiques qui entourent le traitement des infections bactériennes. Cela se comprend facilement si l'on réalise, par exemple, qu'en ne traitant pas diligemment une infection bactérienne à cause d'un choix inadéquat d'antibiotique, on aboutit soit à une hospitalisation, soit à une prolongation du séjour hospitalier ou à une invalidité permanente, voire à un décès, qui auraient tous pu être évités.

$\mathrm{D}$ URING THE PAST FEW YEARS NEW DRUGS WITH GREATLY improved efficacy have become available to physicians and their patients. The higher purchase price of these new drugs is quite important and is quoted as a significant cause of the escalating cost of health care. Antibiotics have played a highly visible role in this therapeutic scene and account for $\$ 1.2$ billion of the yearly national pharmaceutical budget in the United States (1).

Third-generation cephalosporins, quinolones and new macrolide antibiotics are prominent examples that raise the question whether the increased efficacy is worth the price (2). This question is particularly important if one considers that physicians have had to accept, reluctantly, the abandonment of the precept that the interest of the individual patient is paramount because of increasingly expensive therapeutic and diagnostic technology. This comes from the realization that the resources available are not unlimited. This point of view corresponds to the most important economic concept, known as opportunity cost. From an economic point of view costs arise because resources are limited and have alternative uses. The real cost of prescribing a new, more expensive drug, may be that other drugs and/or services become unavailable (either in the health sector or elsewhere) (3). The physician about to prescribe a newer, more expensive drug will not only have to wonder whether the improvement in effectiveness is worth the cost but will also have to estimate whether the economy obtained by prescribing a cheaper drug could have been better used elsewhere in the health care system.

Not surprisingly, considering the magnitude of the stakes, we have seen the recent development and expansion of subsets of the field of health economics. Of these, cost of illness studies and pharmacoeconomics have played a prominent role (4). The ultimate objective of these relatively new tools is to help clinicians and decision makers in setting priorities.

\section{COST OF ILLNESS STUDIES}

The cost of illness is defined to include direct and indirect components (4-6). Direct costs are for resources used to prevent, detect and treat diseases. Indirect costs arise due to the loss of productive output caused by premature mortality, absenteeism and early retirement. Average earnings data standardized for age and sex can be used to value the lost output.

In contrast to these elements, which are often called the 'economic costs' and which are readily quantifiable, one has to consider the psychosocial effects of illness. Since well-being effects such as distress and pain tend to be excluded from the calculations due to their intangible nature, the technique, at best, provides only a very partial estimate of the detrimental effects of the illness.

Another important problem with cost of illness methodology is caused by its use of the human capital theory, which unavoidably biases the estimate towards those diseases that affect mostly fully employed white middle class males. This implies that society accepts that the average male between the ages of 25 and 35 is 1.6 times as valuable (as the earnings indicate) as the average female of comparable age. Society would also have to consider the relative value of unemployed or retired persons.

\section{PHARMACOECONOMICS}

Most clinicians accept that, at some point, spending additional resources for small improvements in clinical outcomes is not worthwhile and represents inappropriate practice. The question is, where should the line be drawn between the patients' good and social cost? Or more specifically, when is a significant and more expensive antibiotic with a slightly better antibacterial coverage indicated? The intention of the new field of pharmacoeconomics is to provide individual physicians, administrators and governments with help on where to draw the line, and thus, to encourage more rational decisions. Reliance on economic analysis has led some countries to require economic evidence to support pricing proposals for new products. Others, such as Australia (7) and Ontario (8), have even published guidelines that clearly describe the form and content of the economic analysis that companies must submit when they are seeking reimbursement status for their medicines.

Pharmacoeconomic analysis, as it is known today, can be divided into cost minimization (also called cost identification), cost effectiveness and cost utility analysis $(4,9)$.

Cost identification: Cost identification analysis has a simple question: "What is the cost?". This may entail, for example, calculating the number of dollars per case treated with one form of therapy and comparing it with the money spent for a similar case treated with an alternative therapy. One cost identification study measured the savings from early hospital discharge of patients suffering from osteomyelitis treated with an out-patient antibiotic treatment (10). The problem with a cost identification analysis is that it does not measure 
the benefit of these expenditures in terms of health outcomes. Thus, cost identification studies are useful only if a drug has both lower cost and better or equal outcomes than its alternative.

Cost effectiveness: Cost effectiveness studies incorporate both cost and effect. They estimate the net cost attached to administering a drug (expenses minus savings) as well as the outcomes obtained. The advantage of cost effectiveness analysis is that it can be used in situations where improved outcomes can be obtained in exchange for the use of more expensive drugs.

Outcomes are reported in a single unit of measurement (eg, years of life saved). For instance, one study compared the cost effectiveness of lowering serum cholesterol levels with two different interventions. The costs were as follows: oat bran, $\$ 17,800.00$ per year of life saved; and cholestyramine, \$59,000.00) (11).

Cost utility: Cost utility analysis is a form of cost effectiveness analysis in which the effectiveness of a treatment on the duration of life is weighted for the quality of life during the years gained (quality adjusted years of life or QUALYS). For example, a year of life with hemiparesis might be equivalent to 0.5 years of life in perfect health, or 0.5 QUALYS.

Perspective of analysis: A pharmacoeconomic study can have different perspectives (4). Cost and benefits can be calculated with respect to the viewpoint of the patients, society, the payers or the health care providers. The perspective chosen for a study determines what is counted as cost or benefit, and therefore the economic impact of an intervention may be quite different depending on the perspective taken. For instance, if a new and effective oral antibiotic allows patients to be discharged earlier from the hospital, the hospital's cost may decrease, but the patient's cost may increase because of the need for out-patient expenses that may not be covered

\section{REFERENCES}

1. Pillans PI, Conry I, Gie BE. Drug cost containment at a large teaching hospital. PharmacoEconomics 1992;1:377-82.

2. Davey PG, Malek MM, Parker SE. Pharmacoeconomics of antibacterial treatment. PharmacoEconomics 1992; 1:409-37.

3. Denby AT, Wells NEJ. Interpreting economic evaluations of medicines: a new role for the pharmacist? PharmacoEconomics 1992;2:95-8.

4. Glossary of terms used in pharmacoeconomic and quality of life analyses. PharmacoEconomics 1993;3:87-9.

5. Shiell A, Gerard K, Donaldson C. Cost of illness studies: an aid to decision-making? Health Policy 1987;8:317-23.

6. Hodgson TA. Cost of illness studies: no aid to decision making? Comments on the Second opinion by Shiell et al (Health Policy, 1987:8: 317-23). Health Policy 1989; 11:57-60.

7. Henry D. Economic analysis as an aid to subsidisation decisions: the development of Australian guidelines for pharmaceuticals. PharmacoEconomics 1992;1:54-67.

8. Detsky AS. Guidelines for economic analysis of pharmaceutical products: a draft document for Ontario and Canada. PharmacoEconomics 1993;3:354-61

9. Eisenberg, JM. Clinical economics: a guide to the by insurance. Even if the study is done from the perspective of society, it may be interpreted in a very different manner by decision makers responsible for different budgets. For instance, a hospital pharmacist may have some difficulties in accepting the benefits of a very expensive intravenous antibiotic that allows the patient to be discharged from the hospital earlier. In the same way, an intravenous antibiotic that can be given only once a day and would thus decrease nursing time would appeal to an economist taking the social perspective, but not to a hospital administrator who might argue that, unless the change diminishes overall staffing or the need for overtime, it is not a saving. This is further confounded by the potential quality of care that nurses with more time may be able to provide to their patients.

\section{RELEVANCE TO ANTIBIOTIC THERAPY}

Pharmacoeconomics is particularly relevant to antibiotic therapy since it can demonstrate that the price of acquisition of the drug plays a relatively modest part in the global pharmacoeconomic aspect of the treatment of bacterial infections. The probability of success and the price of failure are the major components of the economic picture. This is easily understood when we realize that failure to treat a bacterial infection due to an inadequate choice of antibiotic can result in avoidable hospitalization, prolongation of hospitalization, permanent disability and even death. Convincing demonstrations for the high pharmacoeconomic value of properly used third-generation cephalosporins (12), quinolones (13) and aminoglycosides (14) have been published. The use of sequential antimicrobial therapy as a realistic approach to cost containment (15) and the potential savings in hospital costs related to the adoption of a once-daily regimen of a parenteral antibiotic (16) have also been carefully assessed.

economic analysis of clinical practices. JAMA 1989:262:2879-86.

10. Eisenberg JM, Kitz DS. Savings from outpatient antibiotic therapy for osteomyelitis: economic analysis of a therapeutic strategy. JAMA 1986;255:1584-8.

11. Kinosian BP, Eisenberg JM. Cutting into cholesterol: cost-effective alternatives for treating hypercholesterolemia. JAMA 1988;259:2247-54.

12. Gladen HE. Evaluating the cost-effectiveness of treatment with third-generation cephalosporins. Diagn Microbiol Infect Dis 1992;15: 99-105.

13. Balfour JA, Faulds,D. Oral ciprofloxacin: a pharmacoeconomic evaluation of its use in the treatment of serious infections. PharmacoEconomics 1993:3:398-421.

14. Briceland LL, Bailie GR. Cost-effectiveness of gentamicin vs tobramycin. PharmacoEcohnomics 1993:3:251-3.

15. Guay DRP. Sequential antimicrobial therapy: a realistic approach to cost containment? PharmacoEconomics 1993:3:341-4.

16. Eisenberg JM, Koffer H, Finkler SA. Economic analysis of a new drug: potential savings in hospital operating costs from the use of a once-daily regimen of a parenteral cephalosporin. Rev Infect Dis 1984;6:S909. 


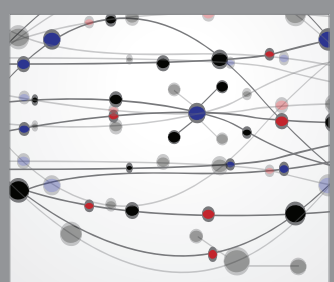

The Scientific World Journal
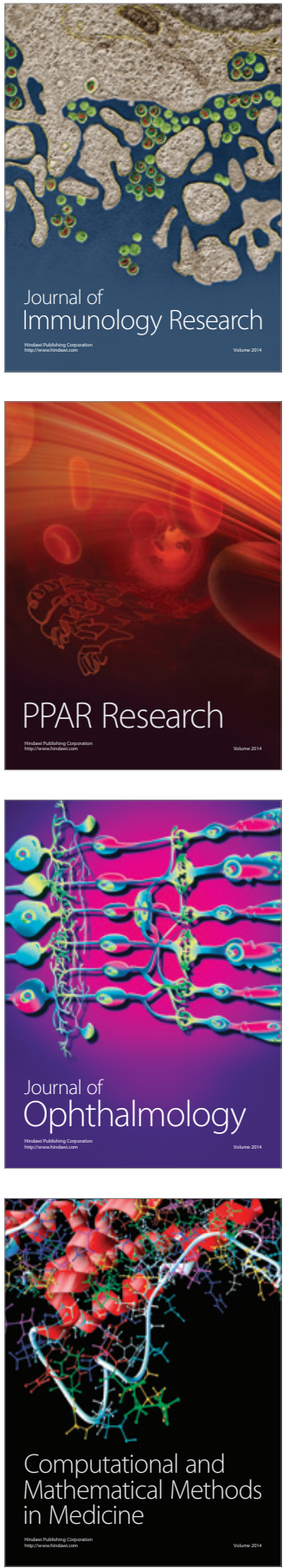

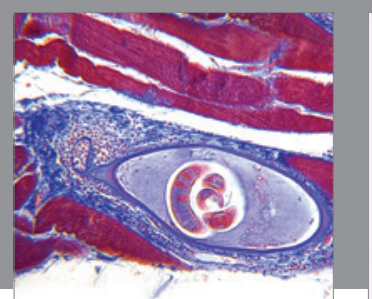

Gastroenterology Research and Practice

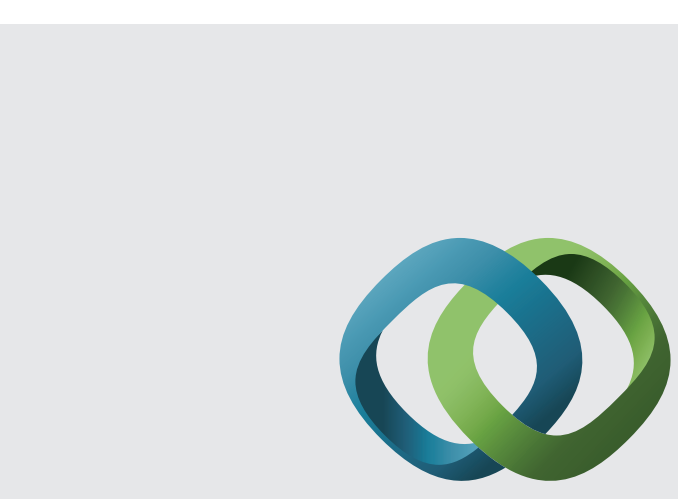

\section{Hindawi}

Submit your manuscripts at

http://www.hindawi.com
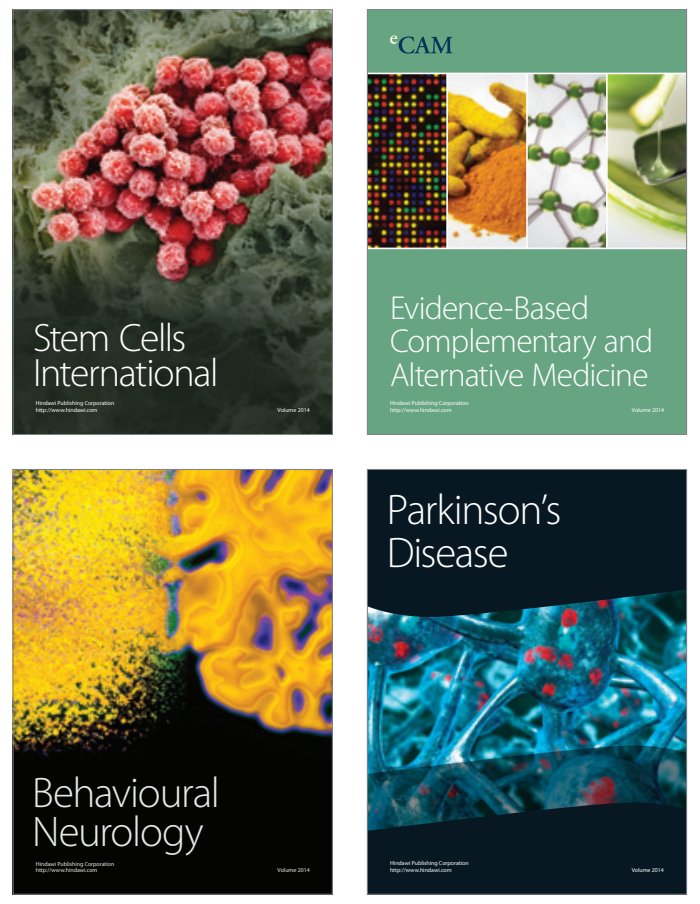
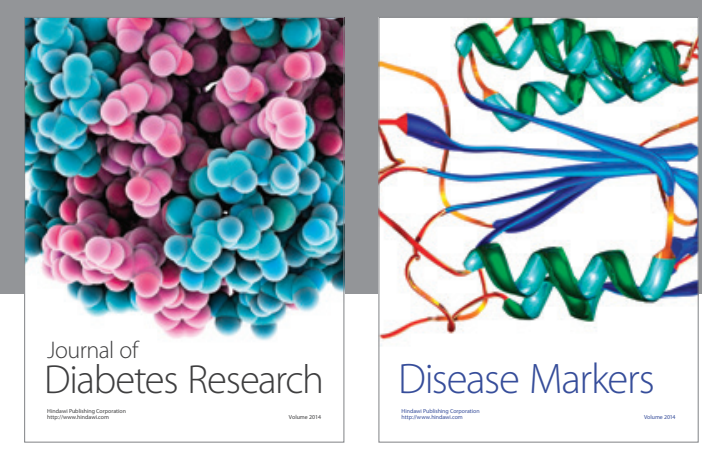

Disease Markers
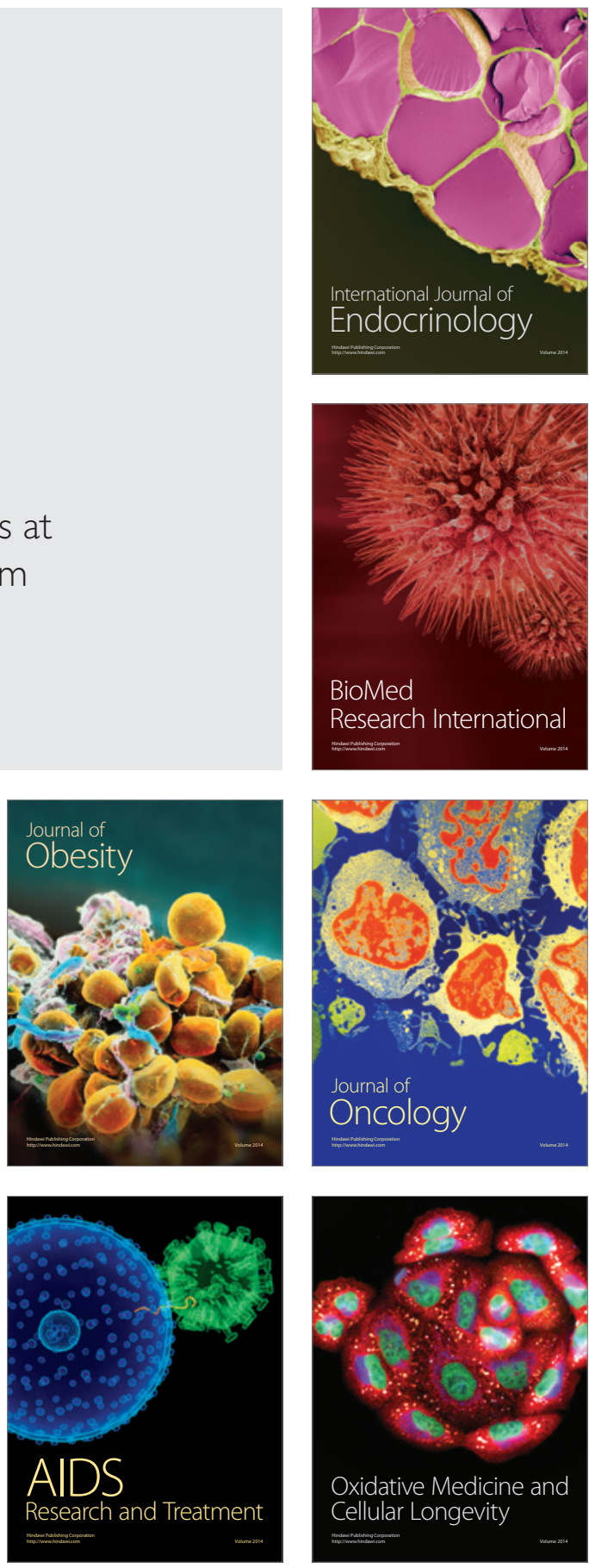